\title{
Evlilik Iletişiminin Etkileme Stratejileri Üzerindeki Rolü Cinsiyet Açısından Farklılaşıyor mu?: Eşlerin Satın Alma Davranışları Üzerine Bir Araştırma
}

\author{
Tuğba KILIÇER *
}

Evlilik İletişiminin Etkileme Stratejileri Üzerindeki Rolü Cinsiyet Açısından Farklılaşıyor mu?: Eşlerin Satın Alma Davranışları Üzerine Bir Araştırma

Özet

$\mathrm{Bu}$ araştırmanın amacı, evlilik iletişiminin eşlerin satın alma sürecinde birbirlerini ikna etmek için kullandıkları etkileme stratejileri üzerindeki etkisini cinsiyet özelinde belirlemektir. Araştırmada veriler sosyal medya platformları üzerinden ulaşılan evli çiftler üzerinden kolayda örneklem tekniğiyle toplanmıştır. Çalışma 280 evli katılımc ile gerçekleştirilmiştir. Verilerin analizinde açıklayıcı faktör analizi ve çoklu regresyon analizinden yararlanılmıştır. Açıklayıcı faktör analizi sonucunda evlilik iletişimin açık iletişim, sohbet odaklılık ve temkinli iletişim boyutlarından oluştuğu tespit edilmiştir. Etkileme stratejileri ise, duygusal tepkiler verme, mantıksal gerekçeler sunma, izlenim yönetimi, bilgi toplamayı önerme, uzmanlık ve yetki gücünü kullanma stratejilerinden oluşmaktadır. Regresyon analizi sonuçları, erkeklerde evlilik iletişiminin erkeklerin yararlandığı etkileme stratejilerini kadınlara göre genel olarak daha iyi açıkladığını göstermektedir. Erkeklerde ve kadınlarda evlilik iletişimi bilgi toplamayı önerme stratejisini diğer stratejilere göre daha iyi açıklamaktadır.

Anahtar Kelimeler: Evlilik iletişimi, Etkileme Stratejileri, Evli Çiftler Married Couples
Key Words: Marital Communication, Influence Strategies,

Is the Role of Marital Communication on Influence Strategies Different to Gender: A Researh on Couples' Purchasing Behavior

\section{Abstract}

The aim of this research is to determine the marriage communication on the strategies that spouses use to persuade each other in the purchasing process with respect to the gender. In research data were collected via married couples reached via social media platforms with convenience sampling. The study was conducted with 280 married participants. Explanatory factor analysis and multiple regression analysis were utilized in the analysis of the data. As a result of explanatory factor analysis, it was determined that marital communication is composed of open communication, chat oriented and cautious communication dimensions. Influence strategies consist of emotional reactions, presenting logical justifications, impression management, proposing information, using expertise and authority. The results of the regression analysis show that marital communication in males generally explains the strategies that affect males more generally than females. Marriage communication in males and females explains the strategy of proposing information better than other strategies.

\section{Giriş}


Tuğba KILIÇER

Evlilik iletişimi, eşler ve aile üyelerini ilgilendiren kararların alınmasında önemli bir role sahiptir. Eşlerin birbirlerine fikirlerini, duygularını, düşüncelerini aktardıkları bu süreçte yaşanan etkileşimin doğası ve düzeyi iletişimin devamı açısından önemlidir. Eşler arasında güçlü ve açık bir iletişimin olduğu evliliklerdeki karar alma süreci, zayıf ve temkinli bir iletişimin olduğu evliliklerden farklılık gösterebilmektedir. Birbirlerine duygu ve düşüncelerini açıklamaktan çekinmeyen, empati gücü yüksek, fikir ayrılıklarını iyi yönetebilen çiftler birbirleriyle daha açık, samimi iletişim kurmakta ve çiftler arasındaki etkileşim kesintiye uğramamaktadır. Eşler arasındaki fikir ayrııklarının çok iyi yönetilemediği, tarafların empati gücünün düşük olduğu, duygu ve düşüncelerin doğrudan açıklanamadığı evliliklerde ise eşlerin birbirleriyle kurdukları iletişim kimi zaman kesintiye uğrayabilmekte, taraflardan biri karşı tarafın tepkilerini göz önünde bulundurarak daha temkinli iletişim kurabilmektedir. Bu durum evlilik ve aileyi ilgilendiren çeşitli kararlar ve durumlar için geçerlidir.

Tüketim ve satın alma kararları evliliklerde alınan kararlar arasında önemli bir yere sahiptir. Bu kararların bir bölümünde eşler arasında fikir birliği sağlanırken, bazı kararların alınmasında eşler arasında fikir ayrılıkları yaşanabilmektedir. Eşler arasındaki tüketim temelli anlaşmazlıkların ortadan kaldırımasında, eşler ortak karar almaya yardımcı olan veya en azından asgari müşterekte buluşmayı sağlayan stratejilere başvurmaktadır. Tarafların birbirlerini kendi tercih ettiği ürün veya hizmet kararına ikna etmeye çalışırken kullandıkları etkileme stratejileri, nihai satın alma kararının verilmesinde etkili olabilmektedir.

Illgili yazın incelendiğinde eşlerin kullandıkları etkileme stratejilerinin neler olabileceği konusunda genel bir çerçevenin ortaya konduğu görülmektedir (Spiro, 1983; Kim ve Lee, 1996; Weigel, Bennett ve Ballard-Reisch, 2006; Falbo ve Peplau, 1980; Gürses, Gülmez ve Kilıçer, 2018). Ancak etkileme stratejilerinin kullanımıyla ilgili cinsiyete özgü farklılıkların olup olmadığı konusunda fikir birliğine varılmadığı söylenebilir (Falbo ve Peplau, 1980; Zvonkovic, Schmiege ve Hall 1994; Weigel vd., 2006). ilgili araştırmalarda etkileme stratejilerinin kullanımını etkileyebilecek öncüllerin de sınırlı sayıda (Aida ve Falbo, 1991; Zvonkovic vd., 1994) araştırmada ele alındığı görülmektedir. Dolayısıyla konuyla ilgili cinsiyet temelinde nedensel ilişkilerin sorgulandığı araştırmalara ihtiyaç olduğu söylenebilir. Falbo ve Peplau'nun (1980) ulaştığı sonuçlar etkileme stratejilerinin kullanımı konusunda cinsiyet özelinde farkıııkların kadın ve erkeğin evlilikteki iletişim eğilimlerinden kaynaklanabileceğine işaret etmektedir. Erkeklerin iletişimde daha doğrudan ve rasyonel bir tarza, kadınların ise daha dolaylı ve duygusal bir tarza sahip olmaları kullanılan stratejilerde farklılığa yol açabilmektedir. Buradan hareketle bu araştırmada evlilik iletişiminin eşlerin satın alma sürecinde birbirlerini ikna etmek için kullandıkları etkileme stratejileri üzerindeki etkisinde cinsiyet özelinde bir farkın olup olmadığı sorusunun yanıtı aranmıştır.

\section{Kavramsal Çerçeve}

\subsection{Evlilik iletişimi}

Iletişim insanların birbirlerini anlamak için duyguları ve anlamları değiş tokuş ettikleri bir süreçtir. Bu süreçte insanlar duygularını, tutumlarını, fikirlerini ve gerçekleri birbirlerine aktarmaktadır. 
Kişiler arası iletişim yalnızca sözcüklerle sınırlı değildir. Dinleme, yüz ifadeleri, jestler, dokunma ve diğer dilsel olmayan semboller ve işaretler de bu süreçte kullanılır. Dolayısıyla kişiler arası iletişim kişilerin birbirlerini etkilemek ve anlamak adına kullandıkları tüm bu araçları içermektedir (Bienvenue, 1975, s. 65; Bienvenue, 1970, s. 26). Etkili iletişim kurma becerisi sosyal yaşamın her anında olduğu evlilik yaşamında da önemli bir role sahiptir. İletişim süreci aile ilişkileri alanının öne çıkan konuları arasındadır. Aile danışmanları ve eğitimciler etkili iletişim kurma yeteneğinin aile üyelerinin zihin sağlığı açısından önemli bir unsur olduğunu belirtmektedir. Bunun yanı sıra etkili iletişim kurma taraflar arasındaki problemlerin çözümünde kaçınılmaz öneme sahiptir. Aile üyeleri arasındaki problemlerin giderilmesinde taraflar arasında kurulan iletişimin doğası ve derecesi oldukça önemlidir (Bienvenue, 1975, s. 66). Aile ve evlilik konularında araştırma yapan birçok araştırmacıya göre evlilik iletişimi, evlilikten duyulan memnuniyetin önemli belirleyicilerinden birisidir. Synder (1979) bir çiftin duygusal iletişim ve problem çözmeye dönük iletişim becerisinin evlilik memnuniyetini en iyi açılayan öncül faktör olduğunu öne sürmektedir.

Evlilik iletişimi konusunda öncü çalışmalara imza atan Bienvenue (1969) evlilik iletişimini eşlerin birbirini anlaması, problemlerini görmesi, farklılıklarını bir kadın ya da erkek bakış açısıyla birbirine aktarması için duyguların ve anlamların değiş tokuş edildiği bir süreç olarak tanımlamaktadır (aktaran Vijayalakshmi, 1997, s. 13). Kişiler arası iletişimine benzer şekilde evlilik iletişimi de farklı yollardan gerçekleşmektedir. Konuşmak, muhabbet etmek iletişimin önemli bir bölümünü oluşturmaktadır. Çiftler evlilikte zaman ilerledikçe birbirleriyle daha açık ve yapıcı şekilde konuşmayı ve daha çok şey paylaşmayı öğrenmelidirler. Evlilik iletişiminde duygu ve düşüncelerin aktarılmasında sözcükler dışında sembollerde kullanılmaktadır. Bazı durumlarda dilsel ve dilsel olmayan mesajlar birbiriyle uyuşmamakta, bu durum çiftler arasında çatışmalara yol açmaktadır (Vijayalakshmi, 1997, s.26). Bienvenue (1970) evli çiftlerde güçlü ve zayıf iletişim arasındaki farkın, çiftlerin gerginliği ve farklılıkları yönetme biçiminden, ses tonundan, anlayış gösterme ve kendini ifade etme yeteneğinden ve iyi dinleme alışkanlıklarından kaynaklandığını vurgulamaktadır. Birçok otorite iyi iletişimin aile etkileşiminde anahtar role sahip olduğunu ve evlilik ilişkisinin can damarı olduğunu iddia etmektedir (Bienvenue, 1970).

\subsection{Etkileme Stratejileri}

Etkileme davranışı 'bir göndericinin alııının duygularını, düşüncelerini ve davranışları değiştirme girişimi' olarak tanımlanmaktadır (Wimalasiri, 2004, s. 275). Bu davranış kişinin iletişim kurduğu kişi ya da kişilerle aynı değerlere, fikirlere sahip olmadığı, düşünce ayrılıklarının olduğu durumlarda karşı tarafı ikna etmek ve çatışmaları azaltmak için kullanılmaktadır. Etkileme davranışı aile yaşam döngüsü içinde de aile üyelerinin başvurduğu davranış biçimlerinden birisidir. Aileyi ilgilendiren farklı konularda çiftler ve çocuklar etkileme stratejilerine başvurmaktadır. Aile yaşam döngüsü içerisinde alınan kararların önemli bir bölümü de tüketimle bağlantılı kararlardır. Bu süreçte alınan kararlar aile üyelerinin bireysel tercihlerinden daha çok ortak karar alma şeklinde gerçekleşmektedir. Ortak karar alma sürecinde seçenekler üzerinde fikir birliği sağlandığı kadar fikir ayrlıkları ve çatışmalarda yaşanmaktadır. Aile tüketimi bağlamında çatışma; aile üyelerinin mevcut finansal kaynaklarla uygun biçimde istek ve ihtiyaçlarını karşılamaya çalışıkları tüketici karar verme süre- 
cinde ortaya çıkan anlaşmazlıklar olarak tanımlanmaktadır (Hamilton, 2009, s. 254). Etkileme stratejileri bu çatışmaların çözümünde ya da çatışma sonucu yaşanan sorunların azaltılmasında başvurulan yollardan birisidir.

Tüketici davranışları alanında etkileme stratejileri ile ilgili araştırmaların daha çok eşler ve çocuklar üzerinde yapıldığı görülmektedir (Palan ve Wilkes, 1997; Willams ve Burns, 2000; Shoham ve Dalakas, 2006; Chaudhary ve Gupta, 2012; Spiro, 1983; Kim ve Lee, 1996). Bu konudaki ilk çaış̧mayı yapan Strodtbeck (1951) karı kocanın birbirlerine görece etkilerini belirlemek istediği araştırmasında aile üyelerine sorduğu bazı hipotetik sorularla her bir aile üyesinin pozisyonunu belirlemiş, aile üyeleri arasında fikir ayrılıkları ortaya çıktığında onlardan sorunu çözmelerini istemiş ve aralarındaki etkileşimi gözlemlemiştir. Kenkel (1963) ise evli çiftlere hediye almak için 300 dolarları olsa, nasıl karar vereceklerini sormuştur. Araştırmacı Bales'in etkileşim süreci teorisine göre çiftler üzerinde gözlem yapmıştır. Araştırma sonunda kadınların ve erkeklerin kullandıkları sözlü yorumların düzeyi ve türü konusunda anlamlı farklılıkların olduğu belirlenmiştir (aktaran: Spiro, 1983, s. 394).

Etkileme stratejileri konusunda yapılan araştırmalarda daha sonra French ve Raven (1959) tarafından geliştirilen "sosyal güç teorisi”nden yararlanılmıştır. Sosyal güç teorisi'nde araştırmacılar diğer insanları etkilemek için yararlanılabilecek beş sosyal gücün varlığını ileri sürmektedir. Bunlar; ödül gücü, zorlayıcı güç, meşru güç, referans gücü, uzmanlık gücüdür. Ödül gücü, taraflardan birinin karşı tarafın kendisini ödüllendirme yeteneğinin olduğunu algılamasıdır. Zorlayıcı güçte, taraflardan biri karşı tarafın cezalandırma gücünün olduğunu algılamaktadır. Meşru güçte, taraflardan biri karşı tarafın öne sürdüğü seçeneğin onun meşru hakkı olduğunu düşünmektedir. Referans gücünde taraflardan biri karşı tarafın kendine referans bir kaynak olduğunu düşünmektedir. Uzmanlık gücü ise, taraflardan birinin karşı tarafın o konuda uzman ve özel bilgiye sahip olduğunu düşünmesidir (French ve Raven, 1959, s. 151).

\subsection{Araştırma Modeli ve Hipotezler}

Illgili yabancı yazın incelendiğinde eşlerin kullandığı etkileme stratejileri ile ilgili sınırlı sayıda çaıışmanın olduğu görülmektedir. Öncü çalışmalardan biri olan Spiro'nun (1983) çalışmasında uzmanlık gücü, meşru kılma, pazarlık etme, etkileme öncesi hoşa giden davranışlar sergileme, duygusal tepkiler verme ve izlenim yönetiminin (Spiro, 1983) eşlerin yararlandığı etkileme stratejileri olduğu ileri sürülmektedir. Kim ve Lee (1996) Spiro'nun (1983) ifade ettiği pazarlık yapma, otorite kullanma, izlenim yönetimi ve duygusal tepkiler verme stratejilerine ek olarak daha fazla bilgi toplamayı önerme, mantıksal nedenler ileri sürme stratejilerinden bahsetmektedir. Falbo ve Peplau (1980) mantıksal nedenler ileri sürme gibi stratejilerin karşı tarafı doğrudan etkilemeye yönelik stratejiler olduğunu, sinirlenme, sessizleşme, surat asma gibi duygusal stratejilerin eşi dolaylı yoldan etkilemeye dönük stratejiler olduğunu belirtmektedir. Bokek-Cohen (2008), bu stratejilerin dışında kullanılan bir başka stratejinin "üçleme stratejisi" olduğunu öne sürmektedir. Üçleme stratejisi diğer eşi etkileyebilme amacıyla üçüncü bir şahsın kullanılması anlamına gelmektedir. Bokek- 
Cohen ve Lissitsa (2010) ise cinselliğin etkileme stratejisi olarak kullanımı konusunda yaptıkları araştırmada evliikteki güç dengesinin bu stratejinin kullanımını etkilediğini vurgulamaktadırlar. Yazındaki araştırma sonuçları çiftlerin bu stratejileri kullanma düzeylerine göre farklı gruplarda yer alabileceğini göstermektedir. Grupların; etkileyemeyenler, az etkileyenler, kurnazca etkileyenler (eşin hoşuna gidecek davranışlar sergileyen eşler), duygusal etkileyenler, stratejileri kombine edenler, çok etkileyenler (Spiro, 1983), uzlaşmacı çiftler (pazarlık yapan, mantıksal argümanları ve bilgi toplamayı öne süren eşler), kadın baskın çiftler, dogmatik çiftler (tüm stratejileri yüksek düzeyde kullanan eşler) ve az etkileyen çiftler (Kim ve Lee, 1996) şeklinde adlandırıldığı görülmektedir.

Yerli yazında ise eşlerin etkileme stratejileri ile ilgili Gürses vd. (2018) dışında bir çalışmaya rastlanamamıştır. İlgili araştırmada yabancı yazındaki çalışmalara benzer şekilde eşlerin satın alma sürecinde eşlerini etkilemek için duygusal tepkiler verme, ikna etme, izlenim yönetimi, bilgi toplamayı önerme, uzmanlık ve yetki gücünü kullanma ve uzlaşmaya varma stratejilerinden yararlandıkları, en çok kullanılan stratejilerin uzlaşmaya varma ve bilgi toplamayı önerme olduğu sonucuna ulaşılmıştır.

Yazındaki keşifsel araştırmalar eşlerin satın alma sürecinde birbirlerini ikna etmek için yararlandıkları etkileme stratejileri ile ilgili bir çerçeve sunmaktadır. Bununla birlikte yazında konuyla ilgili farklııkların ya da nedensel ilişkilerin sorgulandığı araştırmalar çok az sayıdadır. Falbo ve Peplau (1980) heteroseksüel erkeklerin mantıksal argümanları öne sürme gibi doğrudan etki yaratacak stratejilere kadınlara göre daha çok başvurduğu sonucuna ulaşmıştır. Heteroseksüel erkekler aynı zamanda her iki tarafın kazanç elde edeceği çift yönlü stratejileri kadınlara nazaran daha çok kullanmaktadır. Heteroseksüel kadınların ise duygusal tepkiler verme gibi dolaylı stratejileri daha çok kullandıklarını ileri sürülmektedir. Bunun yanı sıra heteroseksüel kadınların pazarlık yapmak yerine istediği ürünü açıkladığı tek yönlü stratejilere erkeklere göre daha çok başvurdukları belirtilmektedir. Zvonkovic vd. (1994) ise kadınların eğitim düzeyi arttıkça duygusal stratejilere daha az başvurduklarını ileri sürmektedir. Weigel vd. (2006) kadınlar ve erkekler arasında yararlanılan stratejiler açısından bir farkın olmadığına, eşlerin doğrudan ve çift yönlü etkileme stratejilerden daha çok yararlandıklarına işaret etmektedir. Aida ve Falbo (1991) geleneksel çiftlerin eşitlikçi çiftlere göre etkileme stratejilerine daha çok başvurduğunu ifade etmektedir. Zvonkovic vd.'de (1994) benzer şekilde geleneksel eğilimlere sahip kadınların ve erkeklerin doğrudan ve dolaylı etkileme stratejilerinden yararlandıklarına vurgu yapmaktadır.

Araştırma sonuçları incelendiğinde kadınlar ile erkekler arasında etkileme stratejilerinden yararlanma konusunda bir farklılı̆ın olup olmadığı, varsa bu farklıı̆ı̆ olası nedenleri ile ilgili fikir birliğinin oluşmadığı ve ampirik araştırmalara ihtiyaç olduğu görülmektedir. Kadınların ve erkeklerin etkileme stratejilerinden yararlanma konusunda farklı eğilimler sergilemesinin çok farklı nedenleri olabilir. Bununla birlikte Falbo ve Peplau'nun (1980) ulaştığı sonuçlar bu farklılığın kadın ve erkeğin iletişim kurma tarzından kaynaklanabileceğini akla getirmektedir. Neticede kadın ve erkek olmak, bireyin iletişim kurma tarzında, amacında ve iletişimden beklentilerinde farklıı̆a yol açabilmektedir. Araştırmalar iletişim kurma amacı bakımından kadınlar ile erkekler arasında farklılığın olduğunu göstermektedir. Kadınlar iletişimi sosyal ilişki kurmak ya da geliştirmek amacıyla kullanır- 
ken, erkeklerin iletişim kurma amacı somut hedeflere, çıtılara ulaşmaktır. Kadınlar daha sosyal ve duygusal iletişimler kurarken, erkekler iletişimde daha rasyonel ve bağımsızdır (Merchant, 2012). Mulac, Bradac ve Gibbons (2001) erkeklerin iletişim kurarken doğrudan, kısa ve öz, kişisel ve araçsal bir dil kullandığını, kadınların ise dolaylı, duygusal ve detaylı dil kullandığını vurgulamaktadır. Basow ve Rubenfield, (2003) kadınların iletişimi güçlendirmeye daha çok önem verdiklerini, bunun için 'problemli sohbetler' yapmaktan kaçınmadıklarını, erkeklerin ise otoritelerini sarsmamak adına bu tür sohbetlerden kaçındıklarını öne sürmektedir. Kadınlar bu tür durumlarda tavsiyede bulunmakta, çözüm önerileri getirmekte iken erkekler böyle bir eğilimden kaçınmaktadır. Maltz ve Borker'a göre (1982) kadınlar sohbeti sürdürmek için erkeklere göre karşı tarafı teşvik edici, cesaretlendirici, aktif bir iletişim tarzına sahiptir. Erkekler fikir ayrılıklarının olduğu durumlarda kadınların sözünü keserken, kadınlar sessizleşerek durumu protesto etmektedir. Kadın ve erkeğe özgü bu eğilimler ve farklılıklar eşler arasında kurulan iletişim de etkileyebilmektedir. Eşler arasındaki iletişimin doğası, düzeyi karar sürecinde karşı tarafı etkilemek için kullanılan stratejilerin kullanımında bir farklılığa yol açabilir. Nitekim evlilik iletişimi üzerine çalışmalar yürüten araştırmacılar, çiftlerin müzakereye ve problem çözmeye dönük iletişim yeteneklerine sahip olmasının, evlilik rollerinin netleşmesinde ve anlaşmazılık, çatışmaların çözümünde önemli bir role sahip olduğunu ileri sürmektedir (Cohen, 1984: 1). Dolayısıyla iletişim konusunda kadın ve erkeğe özgü farklılıkların evlilik iletişiminde ve çiftlerin çatışmanın çözümü için seçtiği stratejilerde farklılığa neden olacağı düşünülmektedir. Bu bağlamda araştırmada aşağıdaki model ve hipotezler geliştirilmiş ve evlilik iletişimi ile etkileme stratejileri arasındaki nedensel ilişkiler cinsiyet özelinde ele alınmıştır.

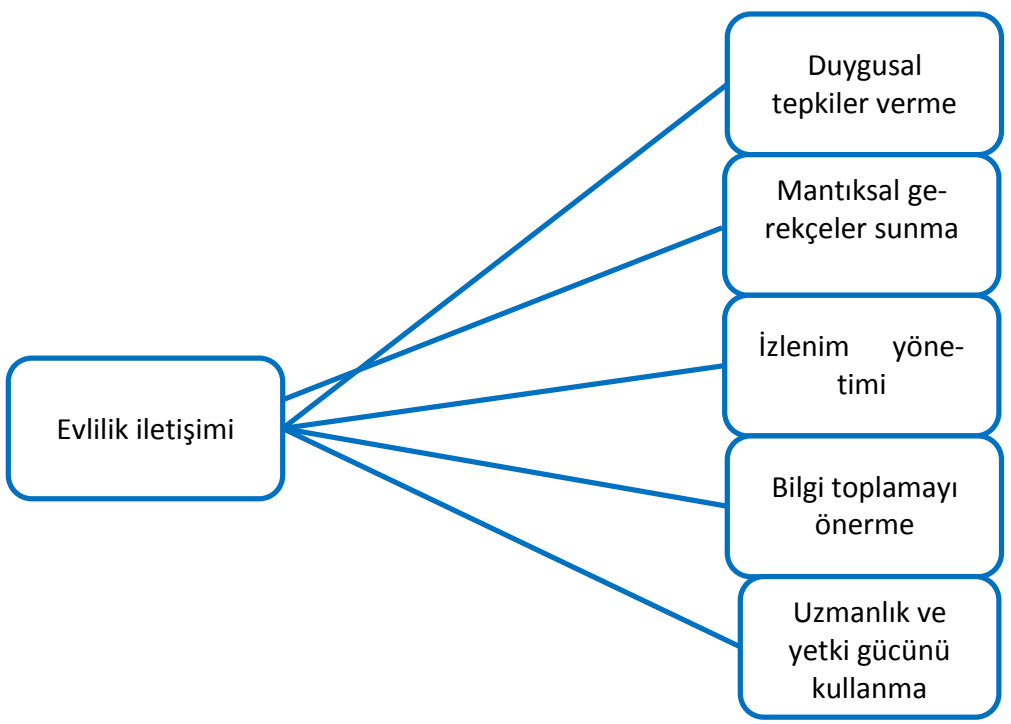

Şekil 1: Araştırma Modeli 
$\mathrm{H}_{1}$ : Evlilik iletişimi boyutları birlikte duygusal tepkiler verme stratejisini anlamlı olarak etkilemektedir.

$\mathrm{H}_{2}$ : Evlilik iletişimi boyutları birlikte mantıksal gerekçeler sunma stratejisini anlamlı olarak etkilemektedir.

$\mathrm{H}_{3}$ : Evlilik iletişimi boyutları birlikte izlenim yönetimi stratejisini anlamlı olarak etkilemektedir.

$\mathrm{H}_{4}$ : Evlilik iletişimi boyutları birlikte bilgi toplamayı önerme stratejisini anlamlı olarak etkilemektedir.

$\mathrm{H}_{5}$ : Evlilik iletişimi boyutları birlikte uzmanlık ve yetki kullanma stratejisini anlamlı olarak etkilemektedir.

\section{Yöntem}

Bu araştırmanın amacı, evlilik iletişiminin eşlerin satın alma sürecinde birbirlerini ikna etmek için kullandıkları etkileme stratejileri üzerindeki etkisini cinsiyet özelinde belirlemektir. Nedensel araştırma modelinin kullanıldığı araştırmada aşă̆ıdaki sorulara cevap aranmıştır:

1. Erkekler açısından evlilik iletişimi etkileme stratejilerini anlamlı bir şekilde yordamakta mıdır?

2. Kadınlar açısından evlilik iletişimi etkileme stratejilerini anlamlı bir şekilde yordamakta mıdır?

Araştırmanın evreni 18 yaş üzeri evli bireylerden oluşmaktadır. Evli kişilere daha hızlı ve kolay ulaşabilmek için katılımcıların belirlenmesinde kolayda örneklem yönteminden yararlanılmıştır. Verilerin toplanmasında çevrimiçi anket tekniği kullanılmıştır. Araştırmacı anket formunu 2018 yılının Mayıs ayında sosyal medya hesaplarından araştırmanın örneklemi içerisinde yer alan tanıdıklarıyla paylaşmış ve anketi cevaplamalarını istemiştir. Paylaşılan kişiler ise kendi hesaplarındaki evli tanıdıklarıyla veri toplama aracını paylaşmışlardır. Bir aylık saha çalışmasının sonucunda toplam 280 katılımcıya ulaşılmıştır. Katılımcıların demografik özellikleri Tablo 1.'dedir. 
Tuğba KILIÇER

Tablo 1. Katılımcıların Demografik Özellikleri

\begin{tabular}{llllllll}
\hline \hline $\begin{array}{l}\text { Demografik } \\
\text { Özellik }\end{array}$ & & $n$ & $\%$ & $\begin{array}{l}\text { Demografik } \\
\text { Özellik }\end{array}$ & & $n$ & $\%$ \\
\hline Cinsiyet & Kadın & 175 & 62,7 & Yaş & $18-25$ & 21 & 7,5 \\
& Erkek & 104 & 37,3 & & $26-35$ & 129 & 46,2 \\
& Toplam & 280 & 100 & & $36-45$ & 98 & 35,1 \\
& & & & & $46-55$ & 25 & 9 \\
& & & & & 56 ve üzeri & 6 & 2,2 \\
\hline Eğitim & Ilkokul & 6 & 2,1 & Aile Geliri & Toplam & 279 & 1600 TL'den az \\
& Ortaokul & 27 & 9,6 & & $1601-3000$ arası & 56 & 1,6 \\
& Lise & 17 & 6,1 & & $3001-4500$ arası & 49 & 19,7 \\
& Üniversite & 142 & 50,7 & & $4501-6000$ arası & 48 & 19,3 \\
& Lisans Üstü & 88 & 31,4 & & $6001-7500$ arası & 38 & 15,3 \\
& Toplam & 280 & 100 & & 7500 TL ve üzeri & 54 & 21,7 \\
& & & & & Toplam & 249 & 100 \\
\hline
\end{tabular}

Katılımcılar cinsiyet açısından incelendiğinde kadınların \% 63'lük oranla önemli bir çoğunluğu oluşturduğu görülmektedir. Yaş bakımından birinci sırada \% 46,2'lik oranla 26 ila 35 yaş arası katıIımcılar yer almaktadır. 36 ila 45 yaş arası katılımcılar \%35'lik oranla ikinci sıradadır. Katılımcıların yarısından fazlası $(\% 50,7)$ üniversite mezunudur. Yüksek lisans ve doktora derecesine sahip katılımcılar \% 31,4'lük oranla ikinci sıradadır. Aylık ortalama gelir açısından incelendiğinde ise 1600 TL ve altında gelire sahip katılımcılar dışında katılımcılar arasında oransal olarak birbirine yakın bir dağılımın olduğu görülmektedir.

Veri toplama aracı iki bölümden oluşmaktadır. Birinci bölümde evililik iletişimi ve etkileme stratejileri ile ilgili $5^{\prime}$ li Likert tipli ifadeler bulunmaktadır. Etkileme stratejileri ile ilgili ifadeler Kim ve Lee'nin (1996) çalışmasından, evlilik iletişimi ile ilgili ifadeler ise Powers ve Hutchinson'ın (1979) çalışmasından yararlanılarak hazırlanmıştır. Etkileme stratejileri 33 ifade, çiftler arasındaki iletişim ise 15 ifade ile ölçülmüştür. Veri toplama aracının ikinci bölümünde ise çiftlerin demografik özelliklerini belirlemeye yönelik kapalı uçlu sorular sorulmuştur.

Araştırmada evlilik iletişimi ve etkileme stratejileri değişkenlerinin yapı geçerliliği açıklayıcı faktör analizi, güvenirlikleri ise Cronbach katsayısı hesaplanarak test edilmiştir. Değişkenler arasındaki nedensel ilişkilerin belirlenmesinde ise çoklu regresyon analizinden yararlanılmıştır.

\section{Bulgular}

\subsection{Açıklayıcı Faktör Analizi ve Ortalamalara iliş̧kin Bulgular}

Eşler arasındaki evlilik iletişiminin yapı geçerliliğini test etmek için açıklayıcı faktör analizi kullanılmıştır. Tablo 2 incelendiğinde KMO değeri ve Bartlett küresellik testi sonuçları verinin faktör analizine uygun olduğunu göstermektedir. KMO değeri 0,890, Bartlett küresellik testi ve Ki-Kare 
değeri anlamlıdır ( $p<.05$ ). 15 madde üç faktör altında toplanmıştır. Birinci faktör eşler arasında samimi ve doğrudan iletişime ilişkin ifadeler nedeniyle açık iletişim, ikinci faktör sohbet etme eğilimlerine ilişkin ifadeler nedeniyle sohbet odaklılık, üçüncü faktör ise iletişimden kaçınmaya dönük ifadeler nedeniyle temkinli iletişim olarak adlandırılmıştır. Faktörler toplam varyansın \% 63,043'ünü açıklamaktadır. Faktörlere ilişkin güvenilirlik katsayıları yüksek ya da kabul edilebilir sınırların üstündedir.

Tablo 2. Evlilik İletişimi Açılayııı Faktör Analizi Sonuçları

\begin{tabular}{|c|c|c|c|}
\hline Maddeler & 1 & 2 & 3 \\
\hline \multicolumn{4}{|l|}{ Açıı iletișim } \\
\hline 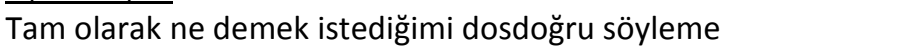 & ,856 & & \\
\hline Samimi sohbetler kurma & ,820 & & \\
\hline İhtiyaçlarını söyleme & ,816 & & \\
\hline Derin sohbetler kurma & 811 & & \\
\hline Ne hissettiğini söylemekten çekinmeme & ,783 & & \\
\hline $\begin{array}{l}\text { Kendini açık iletişim kurabilen biri olarak görme } \\
\text { Sohbet odaklılık }\end{array}$ & ,718 & & \\
\hline$\overline{\text { Akşam sohbetlerini sabırsızlıkla bekleme }}$ & & ,723 & \\
\hline İlişkinin en önemli yönlerini tartışma & & 695 & \\
\hline Fikrimi anlatmayı sabırsızlıkla bekleme & & 685 & \\
\hline Aynı fikirde olmadığımız konularda fikirlerimi söyleme & & 674 & \\
\hline \multicolumn{4}{|l|}{ Temkinli iletişim } \\
\hline Gündelik konularda konuşmada tereddüt etme & & & ,751 \\
\hline İhtiyaçları söylemeye çekinme & & & 706 \\
\hline Sorunlarını kendi çözme & & & 632 \\
\hline Derin konularda sohbet etmekten kaçınma & & & 619 \\
\hline Önemli konularda kafanın allak bullak olması & & & ,563 \\
\hline Özdeğer & 6,356 & 2,025 & 1,076 \\
\hline Açıklanan Varyans (\%) & 42,373 & 13,497 & 7,173 \\
\hline Cronbach $\alpha$ & 0,926 & 0,791 & 0,698 \\
\hline KMO Testi: 0,890 Bartlett Küresellik Testi: $\mathrm{X}^{2}: 2274,990$ df: 105 p 0,00 & & & \\
\hline
\end{tabular}

Kadın ve erkek katılımcıların iletişim eğilimlerine ilişkin ortalamalar Tablo 3'dedir. Ortalamalar incelendiğinde kadınların iletişim eğilimlerinin çok büyük bir fark olmamakla birlikte, erkeklerin önünde yer aldığı görülmektedir. Kadınlar erkeklere göre eşleriyle gündelik sohbetler etmeyi daha sabırsızlıkla beklemekte ve duygu ve düşüncelerini açıklamaktan çekinmemektedir. Bunun yanı sıra kadınların eşleriyle belirli konularda iletişim kurmak konusunda daha temkinli davrandıkları görülmektedir. 
Tuğba KILIÇER

Tablo 3. Katılımcıların Eşleriyle Illetişim Eğilimleri

\begin{tabular}{lcc}
\hline \hline & $\bar{X}$ & \multicolumn{1}{c}{$S$} \\
\hline Erkek & &, 99 \\
Açık iletişim & 3,68 &, 87 \\
Sohbet odaklılık & 3,32 &, 74 \\
Temkinli iletişim & 3,42 & \\
Kadın & &, 85 \\
Açık iletişim & 4,02 &, 82 \\
Sohbet odaklılık & 3,74 &, 76 \\
Temkinli iletişim & 3,65 & \\
\hline
\end{tabular}

Evli çiftlerin satın almayı çok istedikleri ve eşleriyle çatışma yaşadıkları bir üründe karşı tarafı etkilemek için yararlandıkları stratejilerin yapı geçerliliğini test etmek içinde açıklayııı faktör analizinden yararlanılmıştır. Analiz sonuçları Tablo 4'de yer almaktadır. Sonuçlar verinin faktör analizi için uygun olduğunu göstermektedir. Altı madde binişiklik sorunu nedeniyle ölçekten çıkarılmış, kalan 27 madde beş faktör altında toplanmıştır. Toplam varyans büyüklüğü ise \% 60,733'dür. Birinci faktör karşı tarafın hoşuna gidecek tepkiler ya da sessizleşme gibi dikkat çekmeye yönelik tepkiler ilgili ifadeleri içerdiğinden duygusal tepkiler verme, ikinci faktör ürünle ilgili bilgiye ve mantıksal argümanlara dayalı ikna stratejilerini içerdiğinden mantıksal gerekçeler sunma olarak isimlendirilmiştir. Üçüncü faktör tarafların beğendikleri ürünlerin olumlu ya da olumsuz özelliklerini abartmayla ilgili ifadeleri kapsadığı için izlenim yönetimi olarak adlandırılmıştır. Dördüncü faktör başkalarına akıl danışma ve bilgi toplamaya dönük ifadeler nedeniyle bilgi toplamayı önerme şeklinde isimlendirilmiştir. Son faktör ise kadının ya da erkeğin uzmanlık ya da yetki gücüne ilişkin ifadeleri kapsadığı için uzmanlık ve yetki gücünü kullanma olarak isimlendirilmiştir. Bu faktör yapısının literatürdeki farklı araştırmalarda ulaşılan sonuçlarla çoğu faktör bakımından uyumlu olduğu görülmektedir (Spiro, 1983; Kim ve Lee, 1996; Weigel vd., 2006; Falbo ve Peylau, 1980). Faktörlerin güvenilirlik katsayıları incelendiğinde yüksek ya da kabul edilen sınırların üstünde olduğu görülmektedir.

Tablo 4. Etkileme Stratejileri Açıklayııı Faktör Analizi Sonuçları

\begin{tabular}{lccccc}
\hline \hline Maddeler & 1 & 2 & 3 & 4 & 5 \\
Duygusal tepkiler verme & & & & & \\
Nazik tavırlar sergileme &, 856 & & & & \\
Hoşuna gidecek şeyler yapma &, 832 & & & \\
Keyifli bir gününü seçme &, 807 & & & \\
Kabul ederse istediği bir şeyi yapmaya söz &, 740 & & & \\
verme &, 620 & & & \\
Sessizleşme & & & & \\
\hline
\end{tabular}




\begin{tabular}{|c|c|c|c|c|c|}
\hline $\begin{array}{l}\text { Bir önceki sefer senin dediğin oldu diye ikna } \\
\text { etme }\end{array}$ & ,591 & & & & \\
\hline $\begin{array}{l}\text { Ürünü satın alırsa istediği şeyleri yapma } \\
\text { Mantıksal gerekçeler sunma }\end{array}$ & ,565 & & & & \\
\hline Ürüne sahip olmanın önemini anlatma & & ,745 & & & \\
\hline Mantıksal sebeplerle anlatma & & ,743 & & & \\
\hline İkna edici konuşmalar yapma & & ,734 & & & \\
\hline $\begin{array}{l}\text { Kendi seçeneğinin neden iyi olduğunu an- } \\
\text { latma }\end{array}$ & & 679 & & & \\
\hline Ürün konusunda bilgili olduğunu gösterme & & ,604 & & & \\
\hline $\begin{array}{l}\text { Ürünü istediğini söyleme } \\
\text { İzlenim yönetimi }\end{array}$ & &, 535 & & & \\
\hline Olumlu özellikleri abartma & & & ,722 & & \\
\hline Soğuk ve mesafeli davranma & & & ,713 & & \\
\hline Onunla konuşmayacağını söyleme & & & 706 & & \\
\hline Fikrine katılmıyorum diye istediğini yaptırma & & & ,615 & & \\
\hline $\begin{array}{l}\text { Diğer seçenekler konusunda olumsuz ko- } \\
\text { nuşma }\end{array}$ & & & ,589 & & \\
\hline $\begin{array}{l}\text { Eşin istediği ürünün negatif yönlerini abart- } \\
\text { ma }\end{array}$ & & & ,504 & & \\
\hline Bilgi toplamayı önerme & & & & & \\
\hline Daha fazla bilgi toplamayı önerme & & & & ,832 & \\
\hline Akıl danışmasını önerme & & & & 807 & \\
\hline $\begin{array}{l}\text { Her iki tarafın kabul edeceği seçenekler } \\
\text { üzerine konuşma }\end{array}$ & & & & 740 & \\
\hline Ayrı düşülen konularda konuşmayı önerme & & & & 620 & \\
\hline Geçmiş tecrübeleri hatırlatma & & & & ,856 & \\
\hline$\underline{\text { Uzmanlık ve yetki gücünü kullanma }}$ & & & & & \\
\hline $\begin{array}{l}\text { Karar vermenin kendi görevi olduğunu söy- } \\
\text { leme }\end{array}$ & & & & & 738, \\
\hline $\begin{array}{l}\text { Ürün konusunda tecrübeli olduğunu söyle- } \\
\text { me }\end{array}$ & & & & & 717 \\
\hline Ürünü istediğini yüksek sesle dile getirme & & & & & 608 \\
\hline Özdeğer & 8,936 & 3,551 & 1,989 & 1,362 & 1,168 \\
\hline Açıklanan Varyans (\%) & 31,916 & 12,681 & 7,103 & 4,863 & 4,170 \\
\hline Cronbach $\alpha$ & 0,896 & 0,850 & 0,815 & 0,769 & 0,682 \\
\hline
\end{tabular}

Kadın ve erkek katıımcıların etkileme stratejilerinden yararlanma ile ilgili eğilimleri Tablo 5 'de yer almaktadır. Ortalamalar incelendiğinde beş strateji açısından kadın ve erkekler arasında çok belirgin farklııkların olmadığı söylenebilir. Kadın ve erkeklerin en çok yararlandıkları strateji bilgi toplamadır. Bu stratejiden yüksek oranda yararlanmaktadırlar. En çok yararlanılan stratejiler içeri- 
sinde ikinci sırada mantıksal gerekçeler sunma stratejisi gelmektedir. Bu stratejiyi kadınlar erkeklere göre daha çok kullanmaktadır. Duygusal tepkiler verme ile uzmanlık ve yetki gücünü kullanma stratejilerinde her iki grup birbirine yakın eğilimler sergilemektedir. Kadın ve erkeklerin en düşük düzeyde yararlandıkları strateji ise izlenim yönetimidir.

Tablo 5. Katılımcıların Etkileme Stratejilerine İlişkin Eğilimleri

\begin{tabular}{lcc}
\hline \hline & $\bar{X}$ & $S$ \\
\hline Erkek & 2,69 &, 94 \\
Duygusal tepkiler verme & 3,17 &, 89 \\
Mantıksal gerekçeler sunma & 2,08 &, 80 \\
İzlenim yönetimi & 3,51 &, 86 \\
Bilgi toplamayı önerme & 2,62 &, 87 \\
Uzmanlık ve yetki gücünü kullanma & &, 93 \\
Kadın & 2,57 &, 87 \\
Duygusal tepkiler verme & 3,41 &, 75 \\
Mantıksal gerekçeler sunma & 2,04 &, 80 \\
İzlenim yönetimi & 3,50 &, 93 \\
Bilgi toplamayı önerme & 2,73 & \\
Uzmanlık ve yetki gücünü kullanma & & \\
\hline
\end{tabular}

\subsection{Hipotezlerin Test Edilmesi}

Evlilik iletişiminin etkileme stratejilerini anlamlı bir şekilde yordayıp yordamadığını belirlemek için çoklu regresyon analizinden yararlanılmıştır. Analiz öncesinde bağımsız değişkenler arasında çoklubağlantıllık (multi-colinearity) olup olmadığına bakılmıştır. Bunun için öncelikle bağımsız değişkenler arasındaki korelasyona bakılmış, tüm değişkenler arasındaki korelasyon değerlerinin .80'den düşük olduğu görülmüştür (Tablo 6) (Büyüköztürk, 2010). 
Eskişehir Osmangazi Üniversitesi Sosyal Bilimler Dergisi

Tablo 6. Bağımsız Değişkenlere ilişkin Korelasyon Sonuçları

\begin{tabular}{lccc}
\hline \hline & Açık iletişim & Sohbet odaklılık & $\begin{array}{c}\text { Temkinli } \\
\text { iletişimi }\end{array}$ \\
\hline$\underline{\text { Erkek }}$ & 1,0 &, 78 &, 20 \\
Açık iletişim &, 78 & 1,0 &, 05 \\
Sohbet odaklılık &, 20 &, 05 & 1,0 \\
Temkinli iletişim & & &, 52 \\
\hline Kadın & 1,0 &, 72 &, 37 \\
Açık iletişim &, 72 & 1,0 & 1,0 \\
Sohbet odaklılık &, 52 &, 37 & \\
Temkinli iletişim &, 52 & & \\
\hline
\end{tabular}

Daha sonra bağımsız değişkenlerin açıklayamadıkları varyans oranları (tolerans değeri), varyans artış faktörü (VIF) ve durum indeks (Cl) değerlerine bakılmıştır. Tablo 7'de de görüldüğü gibi bağımsız değişkenlerin açıklayamadıkları varyans oranları .20'den büyük, VIF değerinin 10'dan küçük ve $\mathrm{Cl}$ değerinin ise 30'dan küçük çıkmıştır. Buna göre incelenen tüm değerlerin yazında belirtilen (Hair vd., 1998) kabul edilebilir değerlerle uyumlu olduğu ve bağımsız değişkenler arasında çoklubağlantılıık sorununun olmadığı anlaşılmıştır.

Tablo 7. Bağımsız Değişkenlere iliş̧kin Çoklubağlantılılık Test Sonuçları

\begin{tabular}{lccc}
\hline \hline Bağımsız Değişkenler & $\mathrm{Cl}$ & $\begin{array}{c}\text { Tolerans } \\
\text { Değeri }\end{array}$ & VIF \\
\hline Erkek & 6,279 &, 309 & 3,239 \\
Açık iletişim & 12,599 &, 309 & 3,238 \\
Sohbet odaklıık & 18,695 &, 997 & 1,003 \\
Temkinli iletişim & & & \\
Kadın & 5,473 &, 398 & 2,512 \\
Açık iletişim & 16,381 &, 470 & 2,127 \\
Sohbet odaklılık & 20,432 &, 726 & 1,377 \\
Temkinli iletişim & & & \\
\hline
\end{tabular}

Araştırmada değişkenler arasındaki etki düzeyinin cinsiyet özelinde tespit etmek için geliştirilen hipotezler erkek ve kadın katılımcılara göre ayrı ayrı test edilmiştir. Erkek katıımcılara ilişkin regresyon analizi sonuçları Tablo 8'dedir. 
Tuğba KILIÇER

Tablo 8. Erkekler Açısından Evlilik Illetişiminin Etkileme Stratejileri Üzerindeki Etkisine Ilişkin

\begin{tabular}{|c|c|c|c|c|c|c|}
\hline \multicolumn{7}{|c|}{ Bulgular } \\
\hline Bağımlı değişken & Model & $\begin{array}{c}\text { Standart } \\
\text { Beta }\end{array}$ & $t$ & $p$ & $R$ & $R^{2}$ \\
\hline Duygusal tepkiler & Sabit & & 6,857 & ,000 &, $361^{*}$ & $131^{*}$ \\
\hline \multirow[t]{3}{*}{ verme } & Açık iletişim &,- 121 &,- 718 & ,474 & & \\
\hline & Sohbet odaklılık & ,253 & 1,499 & 137 & & \\
\hline & Temkinli iletişim &,- 325 & $-3,464$ & ,001 & & \\
\hline \multirow{4}{*}{$\begin{array}{l}\text { Mantıksal gerek- } \\
\text { çeler sunma }\end{array}$} & Sabit & & 5,299 & ,000 &, $391^{*}$ & $151^{*}$ \\
\hline & Açık iletişim & ,325 & 1,945 & ,055 & & \\
\hline & Sohbet odaklılık &, 043 & ,258 & 797 & & \\
\hline & Temkinli iletişim &,- 168 & $-1,811$ & ,073 & & \\
\hline \multirow[t]{4}{*}{ İlenim yönetimi } & Sabit & & 7,082 & ,000 &, $396^{*}$ & $157^{*}$ \\
\hline & Açık iletişim &,- 153 &,- 916 & ,362 & & \\
\hline & Sohbet odaklılık & ,247 & 1,482 & 141 & & \\
\hline & Temkinli iletişim &,- 370 & $-4,009$ & ,000 & & \\
\hline Bilgi toplamayı & Sabit & & 6,402 & ,000 &, $495^{*}$ & $245^{*}$ \\
\hline \multirow[t]{3}{*}{ önerme } & Açık iletişim & 116 & ,738 & ,462 & & \\
\hline & Sohbet odaklılık & ,350 & 2,223 & ,029 & & \\
\hline & Temkinli iletişim &,- 224 & $-2,558$ & ,012 & & \\
\hline
\end{tabular}

$* p<.01$

Analiz sonucunda erkekler açısından evlilik iletişiminin uzmanlık ve yetki gücünü kullanma stratejisi dışındaki diğer etkileme stratejilerini anlamlı olarak etkilediği belirlenmiştir. Dolayısıyla erkekler açısından $\mathrm{H}_{5}$ hipotezi dışındaki diğer hipotezler kabul edilmiştir. Erkekler açısından açık, sohbet odaklı ve temkinli iletişim biçimleri birlikte satın alma sürecindeki; duygusal tepkiler verme stratejisi ile orta düzeyde anlamlı bir ilişki vermektedir ve toplam varyansın \%13'ünü açıklamakta$\operatorname{dır}\left(R=, 361 R^{2}=, 131 p<.01\right)$. Regresyon katsayılarına göre sadece temkinli iletişim biçimi duygusal tepkiler verme stratejisinin anlamlı yordayıcısıdır. Erkekler açısından açık, sohbet odaklı ve temkinli iletişim biçimleri birlikte mantıksal gerekçeler sunma stratejisi ile orta düzeyde anlamlı bir ilişki vermektedir ve toplam varyansın \%15'ini açıklamaktadır $\left(R=, 391 R^{2}=, 151 p<.01\right)$. Ancak regresyon katsayılarına göre evlilik iletişimi boyutları ayrı ayrı değerlendirildiğinde mantıksal gerekçeler sunma stratejisine anlamlı katkı sağlamamaktadır. Bu durumda açık, sohbet odaklı ve temkinli iletişimin mantıksal gerekçeler sunma stratejisine birlikte katkı sağladığı söylenebilir. Erkekler açısından açık, sohbet odaklı ve temkinli iletişim biçimleri izlenim yönetimi stratejisi ile orta düzeyde anlamlı bir ilişki vermektedir ve toplam varyansın \%16'sını açıklamaktadır $\left(R=, 396 \quad R^{2}=, 157 p<.01\right)$. Regresyon katsayılarına göre sadece temkinli iletişim biçimi izlenim yönetimi stratejisinin anlamlı yordayıcısıdır. Erkekler açısından açık, sohbet odaklı ve temkinli iletişim biçimleri bilgi toplamayı önerme stratejisi ile orta düzeyde anlamlı bir ilişki vermektedir ve toplam varyansın \%25'ini açıkla- 
maktadır ( $\mathrm{R}=, 495 \mathrm{R} 2=, 245 \mathrm{p}<.01$ ). Regresyon katsayılarına göre sohbet odaklılık ve temkinli iletişim biçimleri bilgi toplamayı önerme stratejisine anlamlı katkı sağlamaktadır.

Evlilik iletişiminin kadınlarda etkileme stratejilerini ne düzeyde etkilediğini belirlemek için yapılan çoklu regresyon analizi sonuçları, erkeklerde olduğu gibi kadınlarda da evlilik iletişiminin uzmanlık ve yetki gücünü kullanma stratejisini anlamlı olarak etkilemediğini göstermektedir. Kadınlar açısından evlilik iletişimi ile diğer etkileme stratejileri arasında anlamlı ilişkiler tespit edilmiştir. Böylece kadınlar açısından da $\mathrm{H}_{1}, \mathrm{H}_{2}, \mathrm{H}_{3}$ ve $\mathrm{H}_{4}$ hipotezleri kabul edilmiş, $\mathrm{H}_{5}$ hipotezi ise reddedilmiştir. Analiz sonuçları Tablo 9'da yer almaktadır.

Tablo 9. Kadınlar Açısından Evlilik Illetişiminin Etkileme Stratejileri Üzerindeki Etkisine İlişkin Bulgular

\begin{tabular}{llccccc}
\hline \hline $\begin{array}{l}\text { Bağımlı } \\
\text { değişken }\end{array}$ & \multicolumn{1}{c}{ Model } & $\begin{array}{c}\text { Standart } \\
\text { Beta }\end{array}$ & $t$ & $p$ & $R$ & $R^{2}$ \\
\hline Duygusal & Sabit & & 7.457 &, 000 &, $235^{*}$ & ,055* \\
tepkiler verme & Açık iletişim & -.155 & -1.318 &, 189 & & \\
& Sohbet odaklılık & .248 & 2.292 &, 023 & & \\
& Temkinli iletişim & -.173 & -1.981 &, 049 & & \\
Mantıksal & Sabit & & 7.163 &, 000 &, $257^{*}$ &, $066^{*}$ \\
gerekçeler & Açık iletişim & .315 & 2.692 &, 008 & & \\
sunma & Sohbet odaklılık & -.029 & -.271 &, 786 & & \\
& Temkinli iletişim & -.099 & -1.139 &, 256 & & \\
İzlenim & Sabit & & 9.612 &, 000 &, $252^{*}$ &, $063^{*}$ \\
yönetimi & Açık iletişim & .013 & .107 &, 915 & & \\
& Sohbet odaklılık & -.116 & -1.070 &, 286 & & \\
& Temkinli iletişim & -.194 & -2.237 &, 027 & & \\
Bilgi toplamayı & Sabit & & 7.662 &, 000 &, $295^{*}$ &, $097^{*}$ \\
önerme & Açık iletişim & .181 & 1.560 &, 121 & & \\
& Sohbet odaklılık & .177 & 1.662 &, 098 & & \\
& Temkinli iletişim & -.111 & -1.290 &, 199 & & \\
\hline
\end{tabular}

$* p<.01$

Kadınlar açısından açık, sohbet odaklı ve temkinli iletişim biçimleri birlikte satın alma sürecindeki; duygusal tepkiler verme stratejisi ile düşük düzeyde anlamlı bir ilişki vermektedir ve toplam varyansın \%6'sını açıklamaktadır $\left(R=, 235 R^{2}=, 055 p<.01\right)$. Regresyon katsayılarına göre sohbet odaklıık ve temkinli iletişim biçimleri duygusal tepkiler verme stratejisinin anlamlı yordayıcısıdır. Kadınlar açısından açık, sohbet odaklı ve temkinli iletişim biçimleri birlikte mantıksal gerekçeler sunma stratejisi ile düşük düzeyde anlamlı bir ilişki vermektedir ve toplam varyansın \%7'sini açıklamaktadır $\left(R=, 257 R^{2}=, 066 p<.01\right)$. Regresyon katsayılarına göre sadece açık iletişim biçimi mantıksal gerekçeler sunma stratejisine anlamlı katkı sağlamaktadır. Kadınlar açısından açık, sohbet odakı ve temkinli iletişim biçimleri birlikte izlenim yönetimi stratejisi ile düşük düzeyde anlamlı bir ilişki vermektedir ve toplam varyansın \%6'sını açıklamaktadır $\left(R=, 252 R^{2}=, 063 p<.01\right)$. Regresyon katsa- 
Tuğba KILIÇER

yılarına göre sadece temkinli iletişim izlenim yönetimi stratejisine anlamlı katkı sağlamaktadır. Kadınlar açısından açık, sohbet odaklı ve temkinli iletişim biçimleri birlikte bilgi toplamayı önerme stratejisi ile düşük düzeyde anlamlı bir ilişki vermektedir ve toplam varyansın \%10'unu açıklamaktadır ( $\left.R=, 295 R^{2}=, 097 p<.01\right)$. Bununla birlikte regresyon katsayılarına göre evlilik iletişimi boyutları ayrı ayrı bilgi toplamayı önerme stratejisinin anlamlı yordayıcısı değildir. Açık, sohbet odaklı ve temkinli iletişim bilgi toplamayı önerme üzerinde birlikte anlamlı katkı sağlamaktadır.

\section{Sonuç}

Bu araştırmada evlilik iletişiminin eşlerin satın alma sürecinde birbirlerini ikna etmek için kullandıkları etkileme stratejileri üzerindeki etkisi cinsiyet özelinde ele alınmıştır. Araştırma sonuçları eşlerin birbiriyle kurduğu evlilik iletişiminin; açık iletişim, sohbet odaklılık ve temkinli iletişim boyutlarından oluştuğunu göstermektedir. Bunun yanı sıra çiftler anlaşmazlığın olduğu bir satın alma kararında birbirlerini ikna etmek için; duygusal tepkiler verme, mantıksal gerekçeler sunma, izlenim yönetimi, bilgi toplamayı önerme ile uzmanlık ve yetki gücünü kullanma olmak üzere beş stratejiye başvurmaktadır. Araştırmada evlilik iletişiminin etkileme stratejileri üzerindeki etkisinde cinsiyet özelinde farklııklar tespit edilmiştir. Sonuçlar, erkeklerde evlilik iletişiminin erkeklerin yararlandığı etkileme stratejilerini kadınlara göre genel olarak daha iyi açıkladığını göstermektedir. Erkekler açısından evlilik iletişimi bilgi toplamayı önerme stratejisini diğer stratejilere göre daha iyi açıklamaktadır. Eşleriyle sohbet etmeyi seven, bununla birlikte iletişim konusunda temkinli davranmayı elden bırakmayan erkeklerin eşleriyle bir ürün konusunda anlaşmazık yaşadıklarında eşlerine bilgi toplamayı ve başkalarına akıl danışmayı önerdikleri görülmektedir. Bu durum eşleriyle günlük sohbetleri atlamayan erkeklerin ürün konusundaki anlaşmazlığı daha derin ve somut bilgilerle çözmeyi tercih ettiklerini göstermektedir. Bunun yanı sıra eşleriyle iletişim kurarken temkinli davranan erkeklerin, ikna etmek için eşlerinin hoşuna gidecek duygusal girişimlerde bulundukları ya da ürün hakkındaki bazı bilgileri abartarak eşlerinin olayla ilgili tepkilerini yönetmeye çalıştıkları görülmektedir. Her iki sonuç eşleriyle iletişim konusunda tereddüt yaşayan, her konuda açık davranamayan erkeklerin duygusal manevralarla ya da abartıya başvurarak ürün konusunda kendi tercihlerini kabul ettirmeye çalıştıklarını göstermektedir. Evlilik iletişiminin boyutlarının eşlerini etkilemek için ürün ile ilgili rasyonel argümanları kullanan erkeklerdeki etkisi hakkında ise net bir sonuca ulaşılamamıştır.

Kadınlarda evlilik iletişimi etkileme stratejilerinin kullanımını erkeklere göre daha düşük düzeyde açıklamaktadır. Bununla birlikte erkeklerde olduğu gibi kadınlarda da eşleriyle iletişim konusunda tereddüt yaşamak, her konuda açık davranamamak, kadınları duygusal manevralarla ya da abartıya başvurarak ürün konusunda kendi tercihlerini kabul ettirmeye yöneltmektedir. Eşiyle her konuda rahat iletişim kurabilen kadınların rasyonel argümanlarla erkekleri etkilemeye çalıştıkları görülmektedir. Stratejiler arasında evlilik iletişimini en iyi açıklayan strateji bilgi toplama stratejisidir. Ancak evlilik iletişiminin eşlerini ikna etmek için daha derin ve somut bilgilere ulaşmayı öneren kadınlardaki etkisi hakkında net bir sonuca ulaşılamamıştır. Hem erkekler hem de kadınlar açısın- 
dan evlilik iletişimi ile uzmanlık ve yetki gücünü kullanma stratejisi arasında anlamlı bir ilişki bulunmamaktadır.

Kadınların evlilik iletişiminde erkeklere göre daha açık iletişimden yana olduğu ve derin gündelik sohbetleri önemsediği görülmektedir. Bu sonuçlar Maltz ve Borker (1982) ile Basow ve Rubenfield'ın(2003) ulaştığı sonuçlarla benzerlik göstermektedir. Bununla birlikte erkekler ile kadınlar arasında iletişim eğilimleri açısından keskin bir farkın olmadığı söylenebilir. Falbo ve Peplau'nun (1980) ulaştığı sonuçların aksine kadın ve erkeklerin kullandığı stratejiler de belirgin biçimde farkılışmamaktadır. Kadınların dolaylı ve duygusal, erkeklerin ise doğrudan ve rasyonel eğilimlere sahip olmadıkları görülmektedir. Araştırmada ulaşılan bu sonuç Weigel ve arkadaşlarının (2006) ulaştığı sonuçlarla paralellik göstermektedir. Kadın ve erkeklerin doğrudan anlatımlara başvurdukları ve her iki tarafın kazanç elde etmesine odaklandıkları görülmektedir. Bu durum kadın katılımcıların geleneksel rolleri kabul etmekle birlikte evliliği daha eşitlikçi bir bakış açısıyla değerlendirmelerinden kaynaklanabilir. Bunun yanı sıra kadın ve erkeklerin duygusal tepkilere ve durumu manipüle etmeye yönelik girişimlere çok meyletmedikleri görülmektedir. Tüm bu sonuçlar araştırmaya katılan kadın katılımcıların cinsiyet rolü açısından maskülen ya da androjen, erkeklerin ise feminen ya da androjen eğilimlere sahip olmasından kaynaklanabilir.

Gelecekte yapılacak araştırmalarda cinsiyet rolü ve eşitlikçi rol algısı gibi değişkenlerin dahil edildiği çok boyutlu ölçek araştırmaları tasarlanabilir. Gelecekteki araştırmalarda evlilik iletişimi etkileme stratejileri ilişkisinde aracılık edebilecek ya da öncül değişkenlerin dahil edildiği araştırmalar tasarlanabilir. Kadın ve erkeğe özgü farklııkların daha derinlemesine anlaşılması için gelecekte yapılacak çalışmalarda nitel paradigmadan yararlanılabilir.

Araştırmada ulaşılan sonuçlar doğrultusunda uygulamacıların geliştirecekleri iletişim mesajları ile ilgili öneriler getirilebilir. Uygulamacılar ailenin ortak kullanımına yönelik ürün kategorilerindeki reklam mesajlarında eşler arasındaki etkileşim anlarına yer verebilirler. Uygulamacılar eşlerin önemli ürün kararlarındaki anlaşmazlıkları gidermeye yönelik daha fazla bilgi toplamaya, başkalarına akıl danışmaya teşvik eden iletişim mesajları tasarlayabilirler. Iletişim mesajlarında o ürüne sahip olmanın ne kadar önemli olduğunu gösteren argümanlara da yer verilebilir. Bu argümanlardan satış elemanları kişisel satış sürecinde de yararlanabilirler.

\section{Kaynaklar}

Basow, S. A. \& Rubenfeld, K. (2003). 'Troubles talk': Effects of gender and gender-typing. Sex Roles, 48, 3/4, 183-187.

Bienvenu, Sr., M. J. (1970). Measurement of marital communication. The Family Coordinator, 19,1, 26-31.

Bienvenu, Sr., M. J. (1975). A measurement of premarital communication. The Family Coordinator, 24, 1, 65-68.

Bokek-Cohen, Y.A. (2008). "Tell her she's wrong! Triangulation as a spousal influence strategy. Journal of Consumer Marketing, 25,4, 223-229. 
Tuğba KILIÇER

Bokek-Cohen, Y.A. \& Lissitsa, S. (2010). Sex: The power of the powerless? The use of sex as a spousal influence strategy in vacation purchase decisions. Asia Pacific Journal of Tourism Research, 15,4, 431-448.

Büyüköztürk, Ş. (2010). Sosyal bilimler için veri analizi el kitabı (12. Baskı). Pegem: Ankara.

Chaudhary, M. \& Gupta, A. (2012). Exploring the influence strategies used by children: An empirical study in India. Management Research Review, 35,12, 1153-1169.

Cohen, R. P. (1984). The relationship of communication anxiety and sex role orientation to interpersonal effectiveness and adjustment in marriage. Yayınlanmamış Doktora Tezi, University of Missouri.

Falbo, T. \& Peplau, L. A. (1980). Power strategies in intimate relationships. Journal of Personality and Social Psychology, 38, 618-628.

French, J.R.P. \& Raven, B. (1959). The basis of social power. In Dorwin P. Cartwright (Ed.), Studies in Social Power.

Gürses, F., Gülmez, Y. S. \& Kılıçer, T. (2018). Orta yolu yok mu bu işin? Eşlerin etkileme stratejileri üzerine bir araştırma. 3. Lisansüstü İşletme Öğrencileri Sempozyumu, 12-14 Nisan 2018, Tokat, 557-564.

Hair, J.F., Anderson, R.E., Tatham, R.L. \& Black, W.C. (1998). Multivariate data analysis (5th ed.), New Jersey: Prentice Hall Upper Saddle River.

Hamilton, K. (2009). Consumer decision making in low-income families: The case of conflict avoidance. Journal of Consumer Behaviour, 8, 5, 252-267.

Kim, C. \& Lee, H. (1996). A taxonomy of couples based on influence strategies: The case of home purchase. Journal of Business Research, 36, 2, 157-168.

Maltz, D. N. \& Borker, R. (1982). A cultural approach to male-female miscommunication. In J. J. Gumpertz (Ed.), Language and social identity. Cambridge: Cambridge University Press.

Merchant, K. (2012). How men and women differ: Gender differences in communication styles, influence tactics, and leadership styles. CMC Senior Theses.

Mulac, A., Bradac, J. \& Gibbons, P. (2001). "Empirical support for the gender-as-culture hypothesis an intercultural analysis of male/female language differences", Human Communication Research, 27(1), 121-152.

Palan, K.M. \& Wilkes, R.E. (1997). Adolescent-parent interaction in family decision making. Journal of Consumer Research, 24, 2, 159-169. 
Powers, W. G. \& Hutchinson, K. (1979). The measurement of communication appherension in the marriage relationship. Journal of Marriage and Family, 41, 1, 89-95.

Shoham, A. \& Dalakas, V. (2006). How our adolescent children influence us as parents. Journal of Consumer Marketing, 23, 6, 344-350.

Snyder, D. K. (1979). Multidimensional assessment of marital satisfaction. Journal of Marriage and Family, 41, 4, 813-823.

Spiro, R.L. (1983). Persuasion in family decision-making. Journal of Consumer Research, 9, 4, 393402.

Vijayalakshmi, O. P. (1997). Enriching marital communication and marital adjustment of couples from India living in the United States. Unpublished Thesis, Oragen State University.

Weigel, D. J., Bennett , K. K. \& Ballard-Reisch, D. S. (2006). Influence strategies in marriage: Self and partner links between equity, strategy use, and marital satisfaction and commitment. The Journal of Family Communication, 6, 1, 77-95.

Williams, L.A. \&Burns, A.C. (2000). Exploring the dimensionality of children's direct influence attempts. Advances in Consumer Research, 27, 64-71.

Wimalasiri, J. S. (2004). A cross-national study on children's purchasing behavior and parental response. The Journal of Consumer Marketing, 21, 4/5, 274-284.

Zvonkovic, A. M., Schmiege, C. J. \& Hall, L.D. (1994). Influence strategies used when couples make work-family decisions and their importance for marital satisfaction. Family Relations, 43, 2, 182-188. 